\title{
An Evaluation on Deep Caries Removal Method and Management Performed by Undergraduate Dental Students: A Malaysia Experience
} \author{
Muhammad Syafiq Alauddin ${ }^{2}$ \\ ${ }^{1}$ Faculty of Dentistry, Universiti Sains Islam Malaysia, Kuala Lumpur, \\ Malaysia \\ ${ }^{2}$ Department of Conservative Dentistry and Prosthodontic, Faculty \\ of Dentistry, Universiti Sains Islam Malaysia, Kuala Lumpur, \\ Malaysia \\ ${ }^{3}$ Department of Paediatric Dentistry and Orthodontic, Faculty of \\ Dentistry, Universiti Sains Islam Malaysia, Kuala Lumpur, Malaysia
}

Nurin Izyani Othman ${ }^{1} \quad$ Hanan Umaira Ismail ${ }^{1} \quad$ Norazlina Mohammad ${ }^{2} \quad$ Norzalina Ghazali $^{3}$

\begin{abstract}
Address for correspondence Muhammad Syafiq Alauddin, BDS, DClin Dent, MProstho, RCS, Department of Conservative Dentistry and Prosthodontic, Faculty of Dentistry, Universiti Sains Islam Malaysia, Kuala Lumpur 56100, Malaysia (e-mail: syafiq.alauddin@ gmail.com).
\end{abstract}

\begin{abstract}
Objectives The aim of this study was to investigate the current knowledge and attitude of deep caries removal method among dental students in Malaysia.

Materials and Methods A total of 303 students $(n=303)$ responded to the online questionnaire. The first part of questionnaire was to evaluate the demographic data of the respondents and focused on the technique and management approach used for deep caries lesion. The second part investigated the preferred treatment used for deep caries based on the designated clinical case, while the third part assessed the factors that affected the decision on deep caries management.

Statistical Analysis Independent $t$-test was used to compare difference between the two groups.

Results Seventy four percent of the students have the knowledge of the different methods of caries removal, while $25.8 \%$ were only familiar with complete caries removal. The preferred method for deep caries removal in permanent teeth was partial caries removal (53\%). For primary dentition, $45.6 \%$ of the students prefer to perform

Keywords

- deep caries

- complete removal caries

- partial caries removal

- dental education

- pulpotomy

- conservative dentistry pulpotomy as compared with other techniques. There was no significant difference in caries removal method for permanent teeth between undergraduate year of study $(p>0.05)$, which was partial caries removal at 52.7 and $53.5 \%$, respectively. For primary dentition, the preferred caries removal method was pulpotomy for year 4 (39.8\%) and year $5(52 \%)$ students. The popular material to restore deep caries was resin composite (42\%) followed by glass ionomer cement (23.3\%).

Conclusions This study showed that partial caries removal was the preferred method despite partial understanding on the identification of the clinical indicators of the technique.
\end{abstract}

published online

December 26, 2020
DOI https://doi.org/ $10.1055 / \mathrm{s}-0040-1721546$ ISSN 1305-7456.
(C) 2020. European Journal of Dentistry.

This is an open access article published by Thieme under the terms of the Creative Commons Attribution-NonDerivative-NonCommercial-License, permitting copying and reproduction so long as the original work is given appropriate credit. Contents may not be used for commercial purposes, or adapted, remixed, transformed or built upon. (https://creativecommons.org/licenses/ by-nc-nd/4.0/)

Thieme Medical and Scientific Publishers Pvt. Ltd. A-12, 2nd Floor, Sector 2, Noida-201301 UP, India 


\section{Introduction}

Dental caries is one of the most widespread noncommunicable disease. Deep caries as defined by the International Caries Detection and Assessment System can be removed through various methods. ${ }^{1}$ These methods are complete removal and excavation technique (nonselective removal to hard dentin), partial removal and excavation (selective removal to firm, affected dentin), partial removal and excavation (selective removal to soft, infected dentin) and stepwise caries removal technique. Complete surgical excavation of carious lesion is now considered outdated and an overtreatment since this approach will lead to larger cavities, rapid progress of replacement cycle of restoration, and unnecessary loss of structural integrity of the teeth. ${ }^{2}$ Various systematic reviews and meta-analysis supported on partial excavation of caries removal technique due to results of lower complications of pulpal integrity, such as pulpal necrosis. ${ }^{3-6}$ Currently, the deep caries lesion with compromised pulpal integrity involves vital pulp therapy (VPT) including partial and complete pulpotomy that allows natural rejuvenation of the pulpal biological complex. ${ }^{7}$ The success rate of VPT ranges up to $90 \%{ }^{8-10}$ The advantages include less biological cost, faster and less technique sensitive with the utilization of biomaterials such as mineral trioxide aggregate, bioceramic, and calcium hydroxide $\left[\mathrm{Ca}(\mathrm{OH})_{2}\right]{ }^{11,12}$

This conservative approach is part of the minimal invasive dentistry (MID) that focuses on etiology of the disease. Although the approach of MID had been introduced and advocated in the cariology and dentistry field, there are anecdotal and empirical evidences suggesting that this approach is being practiced in undergraduate clinical years as part of the compulsory training and experience. There is no available evidence regarding MID pedagogy particularly in deep caries management in Malaysian undergraduate dentistry programs. Therefore, this study aims to assess the knowledge and attitude of undergraduate dentistry students in Malaysia on the MID concept for the deep caries removal method.

\section{Materials and Methods}

\section{Study Design}

This study designated as a cross-sectional and quantitative methodology approach approved by the institutional ethical committee (Ref: USIM/JKEP/2019-53) and was conducted from August 2019 to November 2019.

\section{Sample Size}

The sample size calculation was performed by using the Raosoft Sample Size Calculator (Raosoft ${ }^{\circledR}$, Inc., Seattle, WA, United States) (95\% confidence interval). A total of 272 respondents out of 922 of 4th year and 5th year undergraduate dental students in Malaysia were selected to achieve the power calculation with an estimated dropout of $20 \%$ taken into account.

\section{Participants}

A database comprising 4th and 5th year undergraduate dental students was collected from the Malaysian Dental Council online database. Through it, a total of 303 respondents volunteered and completed the questionnaire.

\section{Questionnaire}

The questionnaire was adapted from Crespo-Gallardo et al and was a slight modification according to the needs of this study. ${ }^{13}$ The questionnaire consists of multiple-choice questions with predefined answers offering respondents the possibility to choose several answers. It was validated through a pilot test conducted with 20 undergraduate dental students. The questionnaire was then administered and distributed as an online survey via Google Form with the corresponding link being sent via e-mail and online social platform (WhatsApp).

The questions were organized into three parts. The first part was to evaluate the demographic data of the respondents and focused on the technique and management approach used for deep caries lesion. The questions from the second part investigated the preferred treatment used for deep caries based on the perceived clinical simulation, while the third part of the questionnaire assessed the factors that affected the decision on deep caries management. The questionnaire comprised of (1) details of the respondent; (2) type of deep caries management that was learned in university; (3) management strategy for a deep lesion in a permanent and deciduous dentition with a vital, asymptomatic pulp in an adult patient; (4) factor that affects the management for deep caries lesion; and (5) preferred lining material. The details of the questionnaire are given in - Tables $\mathbf{1}$ to $\mathbf{5}$. The present study focuses on deep carious lesions management and dentine excavation; endodontic procedures were not considered in the present analysis.

\section{Statistical Analysis}

The data from the Google Form were analyzed using Statistical Package for the Social Sciences (SPSS), version 21.0 software (IBM SPSS; IBM Corporation, New York, United States). Independent $t$-test was used for statistical analysis to compare between the 4th and 5th year dental students with regard to the treatment modalities based on designated clinical cases and dentin criteria upon caries removal. A $p$-value with less than 0.05 was considered as statistically significant with the sample set at $95 \%$ of confidence interval. The data was expressed in percentage unit as a result of the questionnaires.

\section{Results}

A total of 303 undergraduate dental students in Malaysia responded to the survey with the response rate of $32.8 \%$. The other $67.2 \%$ did not respond to the questionnaires, although a second reminder was sent via e-mail and other online platform. Among the respondents, 53.1\% were in 4 th year of study, while $46.9 \%$ of them were in 5 th year with $76.2 \%$ made 
Table 1 Sociodemographic, deep caries investigations, and management based on minimally invasive technique

\begin{tabular}{|c|c|c|}
\hline Variables & Percentage (\%) & Frequency \\
\hline \multicolumn{3}{|l|}{ Gender } \\
\hline Male & 23.8 & 72 \\
\hline Female & 76.2 & 231 \\
\hline \multicolumn{3}{|l|}{ Years of study } \\
\hline 4th year & 53.1 & 161 \\
\hline 5th year & 46.9 & 142 \\
\hline \multicolumn{3}{|l|}{ University } \\
\hline Public University & 81.2 & 246 \\
\hline Private University & 18.8 & 57 \\
\hline \multicolumn{3}{|l|}{ Caries removal techniques learned in dental school } \\
\hline Complete caries excavation & 82.7 & 249 \\
\hline Partial caries removal & 60.5 & 158 \\
\hline Stepwise technique & 49.0 & 112 \\
\hline Atraumatic restoration technique & 29.3 & 78 \\
\hline Pulpotomy & 53.2 & 146 \\
\hline Hall technique & 26.7 & 73 \\
\hline Nonrestorative cavity control (NRCC) & 7.6 & 22 \\
\hline \multicolumn{3}{|c|}{ Have you read about the minimal invasive dentistry (MID) approach in cariology field? } \\
\hline Yes & 68.3 & 207 \\
\hline No & 31.7 & 96 \\
\hline \multicolumn{3}{|l|}{ Routinely ask about pain history } \\
\hline Yes & 96.0 & 291 \\
\hline No & 4.0 & 12 \\
\hline \multicolumn{3}{|l|}{ Routinely perform pulp test } \\
\hline Yes & 86.8 & 263 \\
\hline No & 13.2 & 40 \\
\hline \multicolumn{3}{|l|}{ Pulp testing method regularly used: } \\
\hline Cold testing & 82.1 & 249 \\
\hline Hot testing & 35.3 & 105 \\
\hline Electric pulp testing & 89.8 & 244 \\
\hline \multicolumn{3}{|l|}{ Routinely take radiograph } \\
\hline Yes & 89.4 & 271 \\
\hline No & 10.6 & 32 \\
\hline \multicolumn{3}{|l|}{ Type of radiograph taken } \\
\hline Periapical & 84.8 & 257 \\
\hline Bitewing & 22.7 & 69 \\
\hline \multicolumn{3}{|l|}{ Criteria that will stop from further removal based on dentin hardness } \\
\hline Dentin hardness has no influence on my excavation & 7.9 & 24 \\
\hline When the floor is leather like & 8.6 & 26 \\
\hline When the floor of cavity feels hard & 59.1 & 179 \\
\hline $\begin{array}{l}\text { When the floor of cavity feels hard and there is a screeching } \\
\text { Scratch }\end{array}$ & 20.8 & 63 \\
\hline When the floor of cavity is soft & 3.6 & 11 \\
\hline \multicolumn{3}{|l|}{ Criteria that will stop from further removal based on color of dentin } \\
\hline Color of dentin has no influence on my excavation & 7.6 & 23 \\
\hline When the floor of the cavity has a dark stain & 3.3 & 10 \\
\hline
\end{tabular}


Table 1 (continued)

\begin{tabular}{|l|l|l|}
\hline Variables & Percentage (\%) & Frequency \\
\hline When the floor of the cavity has a dark stain (affected dentine) & 65.3 & 198 \\
\hline When the floor of the cavity has a dark stain (infected dentine) & 5.3 & 16 \\
\hline When the floor of the cavity is normal dentin color to yellowish & 18.5 & 56 \\
\hline Criteria that will stop from further removal based on dentin moisture & 42.6 & 129 \\
\hline Moisture has no influence on my excavation & 44.2 & 134 \\
\hline When the floor cavity is dry & 10.9 & 33 \\
\hline When the floor cavity is little moist & 2.3 & 7 \\
\hline When the floor cavity is very moist & & \\
\hline
\end{tabular}

Table 2 Management of deep caries lesion based on the cases analysis

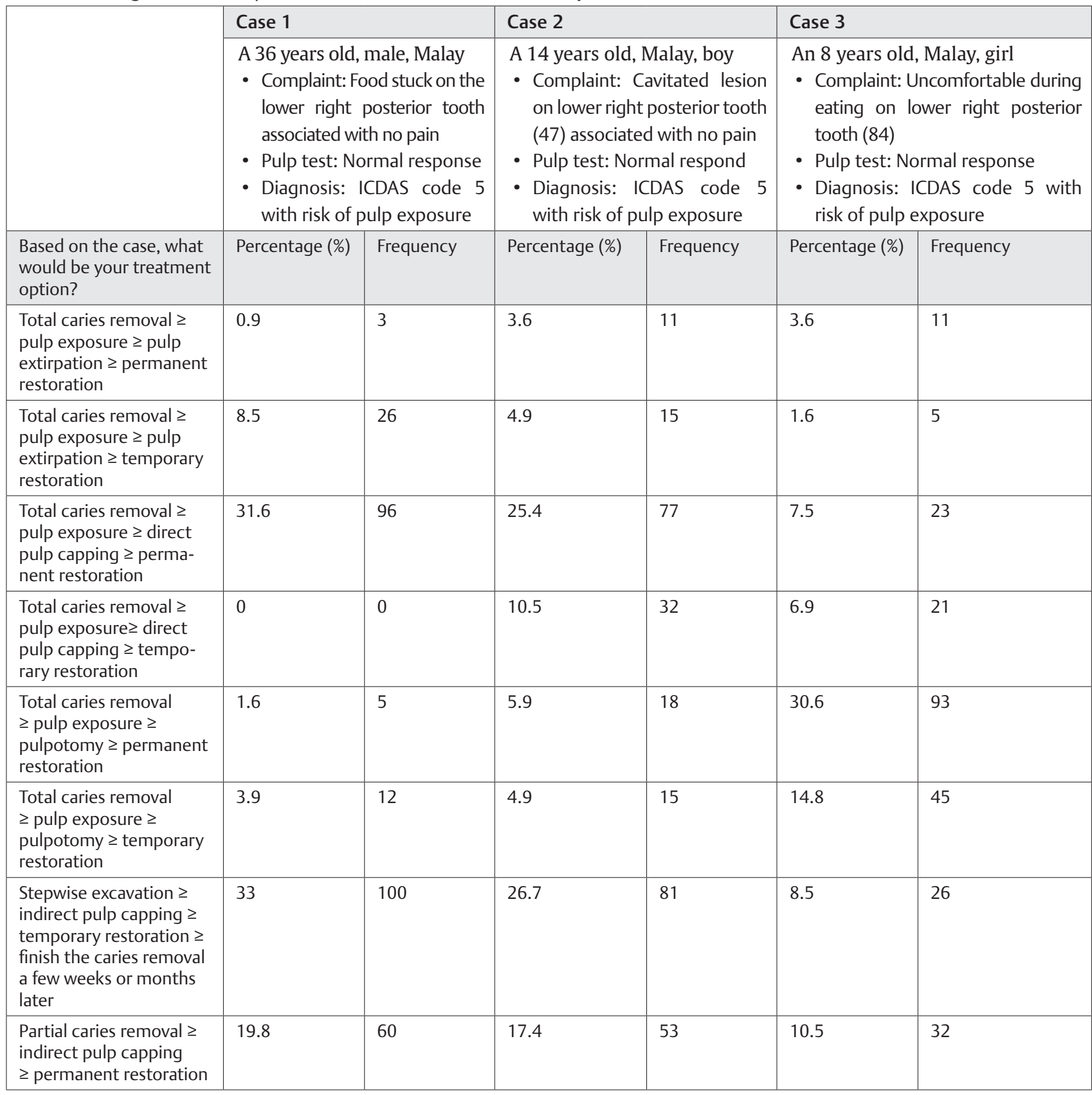


Table 2 (continued)

\begin{tabular}{|c|c|c|c|c|c|c|}
\hline \multirow{3}{*}{$\begin{array}{l} \\
\\
\text { Seal with a crown using } \\
\text { Hall technique without } \\
\text { removing caries }\end{array}$} & \multicolumn{2}{|c|}{ Case 1} & \multicolumn{2}{|c|}{ Case 2} & \multicolumn{2}{|c|}{ Case 3} \\
\hline & \multicolumn{2}{|c|}{$\begin{array}{l}\text { A } 36 \text { years old, male, Malay } \\
\text { - Complaint: Food stuck on the } \\
\text { lower right posterior tooth } \\
\text { associated with no pain } \\
\text { - Pulp test: Normal response } \\
\text { - Diagnosis: ICDAS code } 5 \\
\text { with risk of pulp exposure }\end{array}$} & \multicolumn{2}{|c|}{$\begin{array}{l}\text { A } 14 \text { years old, Malay, boy } \\
\text { - Complaint: Cavitated lesion } \\
\text { on lower right posterior tooth } \\
\text { (47) associated with no pain } \\
\text { - Pulp test: Normal respond } \\
\text { - Diagnosis: ICDAS code } 5 \\
\text { with risk of pulp exposure }\end{array}$} & \multicolumn{2}{|c|}{$\begin{array}{l}\text { An } 8 \text { years old, Malay, girl } \\
\text { - Complaint: Uncomfortable during } \\
\text { eating on lower right posterior } \\
\text { tooth (84) } \\
\text { - Pulp test: Normal response } \\
\text { - Diagnosis: ICDAS code } 5 \text { with } \\
\text { risk of pulp exposure }\end{array}$} \\
\hline & 0 & 0 & 0.3 & 1 & 10.8 & 33 \\
\hline $\begin{array}{l}\text { Nonrestorative cavity } \\
\text { control } \geq \text { apply fluoride }\end{array}$ & 0.3 & 1 & 0 & 0 & 0.9 & 3 \\
\hline $\begin{array}{l}\text { Extraction or review } \\
\text { with extraction if pain or } \\
\text { infection }\end{array}$ & 0 & 0 & 0 & 0 & 3.6 & 11 \\
\hline $\begin{array}{l}\text { Material preferred in } \\
\text { deep caries management }\end{array}$ & \multicolumn{3}{|c|}{ Percentage (\%) } & \multicolumn{3}{|l|}{ Frequency } \\
\hline Amalgam & \multicolumn{3}{|l|}{6.6} & \multicolumn{3}{|l|}{20} \\
\hline Cavit & \multicolumn{3}{|l|}{1.7} & \multicolumn{3}{|l|}{5} \\
\hline Compomer & \multicolumn{3}{|l|}{1.0} & \multicolumn{3}{|l|}{2} \\
\hline Composite & \multicolumn{3}{|l|}{41.7} & \multicolumn{3}{|l|}{127} \\
\hline Glass Ionomer cement & \multicolumn{3}{|l|}{23.3} & \multicolumn{3}{|l|}{71} \\
\hline Giomer & \multicolumn{3}{|l|}{0.4} & \multicolumn{3}{|l|}{1} \\
\hline $\begin{array}{l}\text { Intermediate restorative } \\
\text { material }\end{array}$ & \multicolumn{3}{|l|}{7.6} & \multicolumn{3}{|l|}{23} \\
\hline $\begin{array}{l}\text { Resin modified glass } \\
\text { ionomer cement }\end{array}$ & \multicolumn{3}{|l|}{4.7} & \multicolumn{3}{|l|}{14} \\
\hline Zinc-oxide eugenol & \multicolumn{3}{|l|}{13.1} & \multicolumn{3}{|l|}{40} \\
\hline
\end{tabular}

Abbreviation: ICDAS, International Caries Detection and Assessment System.

Table 3 Independent t-test for treatment based on clinical case. The significance level is set at $p<0.05$

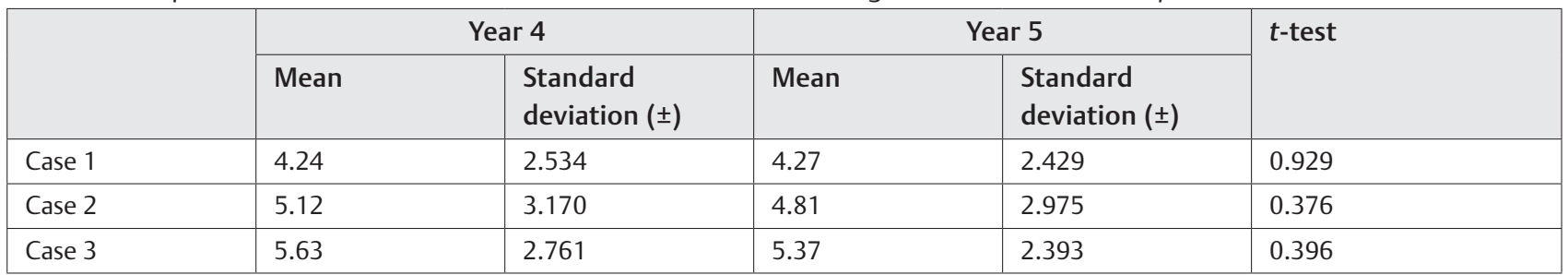

Table 4 Independent t-test for criteria of dentine upon caries removal

\begin{tabular}{|c|c|c|c|c|c|}
\hline & \multicolumn{2}{|c|}{ Year 4} & \multicolumn{2}{|c|}{ Year 5} & \multirow[t]{2}{*}{$t$-test } \\
\hline & Mean & $\begin{array}{l}\text { Standard } \\
\text { deviation }( \pm)\end{array}$ & Mean & $\begin{array}{l}\text { Standard } \\
\text { deviation }( \pm)\end{array}$ & \\
\hline Dentin hardness & 2.70 & 0.928 & 2.89 & 0.731 & 0.048 \\
\hline Dentin color & 3.34 & 1.134 & 3.52 & 1.023 & 0.138 \\
\hline Dentin moisture & 1.78 & 0.772 & 1.67 & 0.712 & 0.186 \\
\hline
\end{tabular}

Note: The significance level is set at $p<0.05$.

up of females and the remaining $23.8 \%$ were male students. The respondents were from public and private universities in Malaysia with the percentage of 81.2 and $18.8 \%$, respectively.
Majority of them had learned various techniques in deep caries management, which include complete caries excavation (82.7\%), partial caries removal (60.5\%), and pulpotomy (53.2\%). 
Table 5 Factors affecting the material of choice, treatment options, and justification

\begin{tabular}{|c|c|c|}
\hline Variables & Percentage (\%) & Frequency \\
\hline \multicolumn{3}{|l|}{ Management of deep caries lesion are affected } \\
\hline Both decision & 91.1 & 276 \\
\hline Self-decision & 0.7 & 2 \\
\hline Supervisor decision & 8.3 & 25 \\
\hline \multicolumn{3}{|l|}{ Preferred material for pulpal lining } \\
\hline Biodentine (Septodont, France) & 2.3 & 7 \\
\hline Calcium hydroxide $\mathrm{Ca}(\mathrm{OH})_{2}$ & 61.4 & 186 \\
\hline Flowable resin composite & 0.3 & 1 \\
\hline Glass ionomer cement (GIC) & 26.7 & 81 \\
\hline Mineral trioxide aggregate (MTA) & 5.9 & 18 \\
\hline Resin modified glass ionomer cement (RMGIC) & 1.3 & 4 \\
\hline TeraCal (resin modified calcium silicate) (BISCO, United States) & 0.3 & 1 \\
\hline Zinc oxide eugenol (ZnOE) & 1.7 & 5 \\
\hline \multicolumn{3}{|l|}{ Preferred material for pulpotomy } \\
\hline Biodentine (Septodont, France) & 5.6 & 17 \\
\hline $\mathrm{Ca}(\mathrm{OH})_{2}$ & 44.2 & 134 \\
\hline Ferric sulfate & 30.7 & 93 \\
\hline Formocresol & 5.6 & 17 \\
\hline MTA & 13.5 & 41 \\
\hline $\mathrm{ZnOE}$ & 0.3 & 1 \\
\hline \multicolumn{3}{|c|}{ Reasons for choosing particular treatment material for treatment intervention } \\
\hline Ease of use, familiarity with the technique & 70.6 & 214 \\
\hline Good clinical result & 74.9 & 156 \\
\hline Recommended by supervisor/colleagues & 61.7 & 147 \\
\hline Recommended by clinical research & 44.8 & 98 \\
\hline Recommended in textbook & 35.9 & 80 \\
\hline Cost-effectiveness & 38.3 & 96 \\
\hline \multicolumn{3}{|l|}{ Factors that affect the treatment choice } \\
\hline Patient's general health & 51.5 & 158 \\
\hline Patient's age & 76.0 & 278 \\
\hline Patient's oral health & 71.1 & 217 \\
\hline Patient's attitude and preference & 70.5 & 216 \\
\hline Type of tooth (anterior, premolar, molar) & 74.6 & 228 \\
\hline Stage of root development (incomplete/complete) & 76.4 & 234 \\
\hline Further restoration needs of tooth & 60.9 & 184 \\
\hline Duration of the total treatment & 42.5 & 131 \\
\hline
\end{tabular}

The students performed the routine history taking and clinical investigations prior to the treatment by investigating the pain history (96\%), performing pulp sensibility testing (86.8\%) and conducting a radiographic examination (89.4\%). It was found that the preferred clinical investigation for deep carious lesion was electric pulp testing (89.8\%) and periapical radiographic view (84.8\%). Majority of the students preferred to stop the caries removal when the procedure reached hard dentin (59\%), when dark stained affected dentine (65\%), and when the floor of cavities was dry (44.2\%) (-Table 1).

Multiple case series with specific scenario and special investigations results were subsequently assessed as reflected in the - Table 2. This was aimed to evaluate the student's attitude on substantial difference in between management of deep caries lesion for permanent, mixed, and primary dentition. The result indicated that more than half of the students (53\%) preferred partial caries removal, while $13.6 \%$ chose to perform total caries removal as their preferred technique for permanent dentition caries removal. As for primary dentition, pulpotomy was favored (45.6\%). There was no significant difference on the preferred technique for permanent dentition between 4 th and 5 th year students, as both chose partial caries removal with the former being $52.7 \%$ and latter $53.5 \%(p<0.929)$. There was also no significant difference 
in preferred caries removal method for immature permanent dentition and primary dentition between 4th and 5th year students as majority chose complete caries removal $(p<0.376)$ and pulpotomy $(p<0.396)$. Nonetheless, both groups have the same preference in partial caries removal. However, there is significant difference in practicing criteria of the caries removal based on the dentine hardness between 4 th and 5th year undergraduate dental students $(p<0.048)$. In total, $41.7 \%$ of the respondents preferred resin composite as the material of choice for deep caries lesion management followed by glass ionomer cement (GIC) (23.3\%) and zinc oxide eugenol (13.1\%).

The factors that influenced the treatment choice for the management of deep carious lesion were also highlighted. Almost $91.1 \%$ of the respondents considered their clinical supervisor's recommendation and self-decision prior to the deep caries management operative procedure. Majority of them preferred to incorporate setting $\mathrm{Ca}(\mathrm{OH})_{2}$ as a lining material (61.4\%) and in pulpotomy cases (44.2\%). The reasons for choosing the type of material were due to the simplicity of use (70.6\%), good clinical result (74.9\%), and recommended by supervisor and/or colleagues (61.7\%). Several factors affected the choices of treatment option for the respondents, among them are the patient's age (76.0\%), patient's oral health $(71.1 \%)$, patient's attitude and preference (70.5\%), type of the tooth (anterior, premolar, or molar) (74.6\%), and the stage of root development (76.4\%).

\section{Discussion}

This cross-sectional study marks the first study on the knowledge and practice of the deep caries management conducted by 4 th and 5th undergraduate dental students throughout Malaysia. Female personnel (76.2\%) and undergraduate dental students from seven major public universities in Malaysia (81.2\%) that offered undergraduate courses on dentistry were the majority participants in this study. Despite the fact that the respondents were only $32.8 \%$ from the total available potential participants, this still represented more than a third of the total 4th and 5th year undergraduate dental students in Malaysia. The Malaysian undergraduate dental students were familiar with an extensive range of basic caries investigation and caries removal techniques including dental pain history, pulp sensibility testing and radiographic investigation with complete, partial, and stepwise caries removal approaches. In this study, we observed that $68.3 \%$ which represented 207 individuals from the overall participants were aware of the MID approach. This showed that there is a paradigm shift in undergraduate dental curriculum and pedagogy toward overall caries management based on MID. The clinical staging of the caries is paramount in determining the overall prognosis, potential treatment plan with suitable preventative measures in managing deep carious lesion. The distinct visibility of the dentine, as well as the soft and leathery on gentle probing, is an indication of the extensive caries classification with active surface lesions. ${ }^{10}$ Nevertheless, in our study, we found that undergraduates had mixed opinions and responses on the necessities to stop caries removal such as dentine color, consistency, and moisture with majority of them choosing to remove hard (59.1\%), dark stained (65.3\%), and dry $(44.1 \%)$ dentine that indicated a complete caries removal approach which was not consistent and contradicted the MID principles.

A series of clinical cases with specific clinical scenario complemented with special investigations and diagnoses were given to investigate the attitude of the participants toward deep caries management practice. In permanent dentition, a third (33\%) of the respondents chose complete caries removal technique with $52.8 \%$ selected stepwise excavation technique and partial caries removal. The approach of the practicing dentists in deep caries management of the permanent teeth is in conflict and showed vast variations in clinical techniques in different parts of the world. A survey to Australian and Finland practicing dentists showed that the majority of the respondents adopted MID approach in which they selected selective and stepwise caries removal with 85 and $64 \%$ in deep caries management, respectively..$^{14,15}$ However, another cohort of dentists in Saudi Arabia and Spain showed the tendency to choose complete caries removal on asymptomatic and symptomatic deep carious lesion with 82.5 and $80 \%$, respectively. ${ }^{13,16}$ In mixed and deciduous dentition cases, 31.3 and $38.1 \%$ opted for complete caries removal in an asymptomatic and healthy pulp, respectively. There was a small cumulative data which analyzed the knowledge and attitude of practicing dentists on the management of deep carious lesion on primary dentition. A nationwide survey conducted by Koopaeei et al showed that the $68 \%$ of the general dentists and $47 \%$ of the endodontists tend to practice complete caries removal as compared with pediatrics dentists who were more likely to opt for selective caries removal. ${ }^{17}$ Another survey by Muller-Bolla et al showed the same trend in which majority of the dentists (68\%) chose complete caries removal in a single visit. ${ }^{18}$ Amalgam is still the preferred choice for deep caries restorative materials for a small number of respondents (6.6\%) even though the collaborative focus on utilizing resin composite in MID era. ${ }^{19} \mathrm{~A}$ consistency in knowledge and preference was detected for case series analysis of deep caries management between 4th and 5th year dental students ( $\mathbf{- T a b l e} \mathbf{3}$ ). However, there was a significance tendency $(p<0.05)$ of complete caries removal in 4th year as compared with 5 th year undergraduate dental students in the dentine hardness perspective as the indicator for deep carious lesion. A clinical experience in the context of advancing years of study influenced the decision and competency for the partial caries removal technique. In this study, there is a need for an instant response on educating future dentists in shifting the attitude toward selective caries removal in the domain of deep caries management.

A clear majority of $91.1 \%$ respondents decided that both factors of supervisors and self-decision are needed to achieve a clinical agreement on management for deep caries lesion that in turn reflected a dependency on the clinical faculty members. One of the paramount concepts in MID is to maintain pulp vitality in an already inflamed pulp-dentine complex. The main aim of pulp capping is to protect the pulp tissue complex from potential irritation particularly bacteria in nature. ${ }^{20}$ 
About $88.1 \%$ of the respondents selected $\mathrm{Ca}(\mathrm{OH})_{2}$ and $\mathrm{GIC}$ as the preferred materials used in pulpal lining that are in line with the recommendation and results showed from other studies. ${ }^{21-23}$ Pulpotomy is a routinely performed clinical procedure with high clinical success to eliminate bacteria followed by the placement of a suitable material or medicament within the pulp chamber complex to maintain vitality of primary teeth until exfoliation to prevent the need of pulpectomy. ${ }^{24}$ Approximately two-third of the respondents (74.9\%) selected $\mathrm{Ca}(\mathrm{OH})_{2}$ and ferric sulfate as the material of choice that is parallel with the current literature advocating material selection for pulpotomy. An emerging popularity of MTA as the superior material of choice is reflected in this study as well with $13.5 \%$ respondents choosing it. However, the number is lesser due to the probability of high material cost and potential risks of tooth discoloration. ${ }^{25-27}$ Nevertheless, $5.6 \%$ of the respondents still chose formocresol as the material of choice despite its known issue for toxicity. ${ }^{28}$ More than two-third of the respondents gave the reason to their preferred material due to relatively ease of clinical usage with good clinical results that depicted the clinical techniques and the evidence-based outcome of this material that is well described in the undergraduate curriculum policy and content. A comprehensive list of the factors that affects the treatment choice chosen and description by the respondents is also included in this study as well. The patient's age, overall oral health, attitude, and preference toward the treatment proposed, type, and location of the tooth and stage of root development were the most patient-related factors taken into account for treatment of choice.

The major limitation in this study is that the total participants merely consist of only one third of 4th and 5th year undergraduate dental students in Malaysia. More recruitment of participants from nation-wide dental schools will promise a true reflection of knowledge, attitude, and practice of deep caries management for this study.

\section{Conclusions}

The partial caries removal technique in deep caries management is well adopted and implemented in undergraduate curriculum design and content based in this nation-wide survey on undergraduate students in Malaysia. However, there is a partial understanding on the practice of this approach reflected by the survey in the case discussion analysis. Maximum efforts should be made to translate the growing evidence of partial, conservative caries removal into the curriculum syllabus in managing deep carious lesion. There is an urgent need to enhance the MID pedagogy regarding preclinical and clinical education training on the partial caries removal method in undergraduate dental curriculum in Malaysia.

\section{Funding}

The study was supported by Universiti Sains Islam Malaysia, Malaysia (USIM) Internal Grant (PPPI/ FPG/0217/051000/11918).

\section{Conflict of Interest}

None declared.

\section{Acknowledgment}

The authors wish to thank Dr. Aspalilah Alias, Department of Oral Biology \& Basic Science, Universiti Sains Islam Malaysia, for helping with statistically analysis.

\section{References}

1 Pitts NB, Ismail AI, Martignon S, Ekstrand K, Douglas GV, Longbottom C. ICCMS ${ }^{\mathrm{TM}}$ Guide for Practitioners and Educators. London: King's College London: 2014

2 Schwendicke F, Innes N, Removal strategies for carious tissues in deep lesions. In: Management of Deep Carious Lesions: Springer; Cham; 2018 15-35

3 Barros MMAF, De Queiroz Rodrigues MI, Muniz FWMG, Rodrigues LKA. Selective, stepwise, or nonselective removal of carious tissue: which technique offers lower risk for the treatment of dental caries in permanent teeth? A systematic review and meta-analysis. Clin Oral Investig 2020;24(2):521-532

4 Hoefler V, Nagaoka H, Miller CS. Long-term survival and vitality outcomes of permanent teeth following deep caries treatment with step-wise and partial-caries-removal: a systematic review. J Dent 2016;54:25-32

5 Li T, Zhai X, Song F, Zhu H. Selective versus non-selective removal for dental caries: a systematic review and meta-analysis. Acta Odontol Scand 2018;76(2):135-140

6 Schwendicke F, Dörfer CE, Paris S. Incomplete caries removal: a systematic review and meta-analysis. J Dent Res 2013;92(4):306-314

7 Simon S, Perard M, Zanini M, et al. Should pulp chamber pulpotomy be seen as a permanent treatment? Some preliminary thoughts. Int Endod J 2013;46(1):79-87

8 Ali AH, Koller G, Foschi F, et al. Self-limiting versus conventional caries removal: a randomized clinical trial. J Dent Res 2018;97(11):1207-1213

9 Hashem D, Mannocci F, Patel S, Manoharan A, Watson TF, Banerjee A. Evaluation of the efficacy of calcium silicate vs. glass ionomer cement indirect pulp capping and restoration assessment criteria: a randomised controlled clinical trial-2-year results. Clin Oral Investig 2019;23(4):1931-1939

10 European Society of Endodontology (ESE) developed by:, Duncan HF, Galler KM, et al. European Society of Endodontology position statement: Management of deep caries and the exposed pulp. Int Endod J 2019;52(7):923-934 doi: $10.1111 /$ iej.13080

11 Shahid S, Duminis T, Glass-Ionomer Cement: Chemistry and Its Applications in Dentistry. Advanced Dental Biomaterials. Woodhead Publishing, Cambridge, United Kingdom; 2019 175-195

12 Najeeb S, Kurshid Z, Ghabbani H, Zafar MS, Sefat F. Nano Glass Ionomer Cement: Modification for Biodental Applications. Advanced Dental Biomaterials. Woodhead Publishing, Cambridge, United Kingdom; 2019 217-227

13 Crespo-Gallardo I, Martín-González J, Jiménez-Sánchez MC, Cabanillas-Balsera D, Sánchez-Domínguez B, Segura-Egea JJ. Dentist's knowledge, attitudes and determining factors of the conservative approach in teeth with reversible pulpitis and deep caries lesions. J Clin Exp Dent 2018;10(12):e1205-e1215

14 Chai B, Tay B, Chow C, Fuss J, Krishnan U. Treatment preferences for deep caries lesions among Australian dentists. Aust Dent J 2020;65(1):83-89 
15 Croft K, Kervanto-Seppälä S, Stangvaltaite L, Kerosuo E. Management of deep carious lesions and pulps exposed during carious tissue removal in adults: a questionnaire study among dentists in Finland. Clin Oral Investig 2019;23(3):1271-1280

16 Alnahwi TH, Alhamad M, Majeed A, Nazir MA. Management preferences of deep caries in permanent teeth among dentists in Saudi Arabia. Eur J Dent 2018;12(2):300-304

17 Koopaeei MM, Inglehart MR, McDonald N, Fontana M. General dentists', pediatric dentists', and endodontists' diagnostic assessment and treatment strategies for deep carious lesions: a comparative analysis. J Am Dent Assoc 2017;148(2):64-74

18 Muller-Bolla M, Garcia A, Aïem E, Doméjean S. Dentists' decisions for deep carious lesions management in primary teeth. Int J Paediatr Dent 2020;30(5):578-586

19 Banerjee A. Minimal intervention dentistry: part 7. Minimally invasive operative caries management: rationale and techniques. Br Dent J 2013;214(3):107-111

20 Bjørndal L, SimonS, Tomson PL, Duncan HF. Management of deep caries and the exposed pulp. Int Endod J 2019;52(7):949-973

21 Singh S, Mittal S, Tewari S. Effect of different liners on pulpal outcome after partial caries removal: a preliminary 12 months randomised controlled trial. Caries Res 2019;53(5):547-554

22 da Rosa WLO, Lima VP, Moraes RR, Piva E, da Silva AF. Is a calcium hydroxide liner necessary in the treatment of deep caries lesions? A systematic review and meta-analysis. Int Endod J 2019;52(5):588-603
23 Shameem A, Muliyar S, Thankachan RP, Kalliath JT, Mangalath U, Mangalath S. Study to evaluate the efficacy of resin-modified glass ionomer cement liner as a direct pulp capping material. J Contemp Dent Pract 2018;19(9):1065-1071

24 Taylor GD, Vernazza CR, Abdulmohsen B. Success of endodontic management of compromised first permanent molars in children: a systematic review. Int J Paediatr Dent 2019

25 Bossù M, Iaculli F, Di Giorgio G, Salucci A, Polimeni A, Di Carlo S. Different pulp dressing materials for the pulpotomy of primary teeth: a systematic review of the literature. J Clin Med 2020;9(3):838

26 Abuelniel GM, Duggal MS, Kabel N. A comparison of MTA and Biodentine as medicaments for pulpotomy in traumatized anterior immature permanent teeth: A randomized clinical trial. Dent Traumatol 2020;36(4):400-410

27 Pulikkotil SJ, Veettil SK, Vineet Dhar BD. Effectiveness of formocresol and ferric sulfate as pulpotomy material in primary molars: a systematic review and meta-analysis with trial sequential analysis of randomized clinical trials. Quintessence Int 2019;50:2-15

28 Ko H, Jeong Y, Kim M. Cytotoxicities and genotoxicities of cements based on calcium silicate and of dental formocresol. Mutat Res 2017;815:28-34 